\title{
Modelling soil erosion risk based on RUSLE-3D using GIS in a Shivalik sub-watershed
}

\author{
SURESh Kumar ${ }^{1, *}$ and S P S Kushwaha ${ }^{2}$ \\ ${ }^{1}$ Agriculture and Soils Department, Indian Institute of Remote Sensing, ISRO, Dehradun 248 001, India. \\ ${ }^{2}$ Forestry and Ecology Department, Indian Institute of Remote Sensing, ISRO, Dehradun 248 001, India. \\ ${ }^{*}$ Corresponding author.e-mail: suresh_kumar@iirs.gov.in
}

The RUSLE-3D (Revised Universal Soil Loss Equation-3D) model was implemented in geographic information system (GIS) for predicting the soil loss and the spatial patterns of soil erosion risk required for soil conservation planning. High resolution remote sensing data (IKONOS and IRS LISS-IV) were used to prepare land use/land cover and soil maps to derive the vegetation cover and the soil erodibility factor whereas Digital Elevation Model (DEM) was used to generate spatial topographic factor. Soil erodibility $(\mathrm{K})$ factor in the sub-watershed ranged from 0.30 to 0.48 . The sub-watershed is dominated by natural forest in the hilly landform and agricultural land in the piedmont and alluvial plains. Average soil loss was predicted to be lowest in very dense forest and highest in the open forest in the hilly landform. Agricultural land-1 and agriculture land-2 to have moderately high and low soil erosion risk, respectively. The study predicted that $15 \%$ area has 'moderate' to 'moderately high' and $26 \%$ area has high to very high risk of soil erosion in the sub-watershed.

\section{Introduction}

The Shivalik region, occupying nearly $2.14 \mathrm{M}$ ha area in the north-western Himalaya, is characterized as the most fragile landscape in India (Dhruva Narayana 1987; Sidhu et al. 2000). The landscape is affected by moderate to severe soil erosion due to water, thus playing a major role in land degradation process in the region. Rate of soil erosion was found to be greater in the Shivaliks compared to other physiographic regions in India (Singh et al. 1992) due to steep terrain, poor vegetal cover, unstable geology and immature soil conditions (Valdiya and Bartarya 1989). The combined impact of these factors leads to continuous depletion in the fertility and productivity of soil as well as deterioration in the water quality (Lal 1998).
High soil erosion causes sedimentation of reservoirs, resulting in severe economic losses to irrigation and hydroelectric projects (Arya and Samra 2001).

Several watershed development programmes are being implemented by State and Central Governments to conserve soil against erosion and to improve the soil fertility for sustainable development of natural resources. Soil water erosion is a very dynamic spatial phenomenon. The information on the spatial extent of erosion risk area and its severity are pre-requisites for soil conservation planning and watershed management programmes. Spatial patterns of erosion risk are too complex and conventional method of mapping these lands based on field survey does not provide spatiallyexplicit information. Erosion models can be used as

Keywords. RUSLE-3D model; DEM; Shivalik hills; sub-watershed; soil erosion risk potential. 
predictive tools for assessing soil loss and soil erosion risk for conservation planning (Popp et al. 2000).

Several erosion models are available to predict the soil loss and to assess the soil erosion risk. The Universal Soil Loss Equation (USLE), an empirical model (Wischmeier and Smith 1978) or RUSLE model (Renard et al. 1997) are widely used to predict potential soil water erosion. RUSLE uses the same empirical principles as USLE, but includes numerous improvements in computation of various factors. It predicts longtime average annual soil loss as a product of rainfall erosivity $(R)$, soil erodibility $(K)$, slope length $(L)$, terrain steepness $(S)$, vegetation cover $(C)$ and conservation practices $(P)$ factors. Among these factors, topographic factor is the most sensitive in the prediction of soil loss (Risse et al. 1993). The product of slope length $(L)$ and slope steepness $(S)$ factor represents the topographic factor $(L S)$. The slope length in the USLE model is defined as the distance from the point of origin of overland flow to either where the slope decreases to the point that deposition begins, or to the point where runoff entered a well defined channel (Wischmeier and Smith 1978). Slope length is defined as overland-flow path-length in RUSLE2 for its wider application (Renard et al. 1991). An overland flow path length is defined as distance from the origin of overland flow to where it enters a major concentrated flow area like an ephemeral gully, waterway, diversion, or stream (Renard et al. 1997). This definition helps in spatial prediction of topographic factor $(L S)$ equation based on a digital elevation model (DEM) (Moore and Burch 1986; Moore and Wilson 1992; Desmet and Govers 1996). Mitasova et al. (1996) replaced the slopelength factor $(L S)$ by the upslope contributing area in RUSLE-3D. Upslope contributing area can be approximated easily using flow accumulation. The merit of replacing the slope length by upslope area lies in the fact that the upslope area better reflects the impact of concentrated flow on increased erosion as normally witnessed in the hilly landscape. The RUSLE/RUSLE-3D model has been widely used for spatial prediction of soil loss and erosion risk potential (Millward and Mersey 1999; Lu et al. 2004; Shi et al. 2004; Efe et al. 2008; Terranova et al. 2009; Park et al. 2011).

In recent years, the availability of high resolution satellite data has facilitated in large-scale inventory of land use/land cover and soil resources up to micro-watershed level. Several GIS software provide in-built tools for computation of terrain attributes from DEM to estimate the slope length and slope steepness factors. The present study aims to assess the spatial pattern of soil erosion risk in Pathri Rao sub-watershed using RUSLE-3D model.

\section{Study area}

The Pathri Rao sub-watershed (figure 1) lies in the Shivalik physiographic region of Haridwar district in Uttarakhand province between $29^{\circ} 55^{\prime}-30^{\circ} 03^{\prime} \mathrm{N}$ latitudes and $77^{\circ} 59^{\prime}-78^{\circ} 07^{\prime} \mathrm{E}$ longitudes. It covers an area of $44 \mathrm{~km}^{2}$. The area is drained by the river Pathri Rao and its tributaries - the Chirak Rao and the Harnaul Rao. Nearly $27.4 \%$ area of the subwatershed is hilly and belongs to Rajaji National Park. Elevation in the sub-watershed ranges from 250 to $900 \mathrm{~m}$ above msl. Geologically, the area is divided into three zones, viz., Shivalik hills, piedmont, and the alluvial plains from north to south (IIRS 2007). Shivalik hills comprise of tertiary group of rocks and contains boulders, pebbles, sand, and the clay. The boulders and pebbles are mostly of quartzite, micaceous sandstone and siltstone (CGWB 2009). The hills have high relief and deep-incised drainage with steep and sharp hill slopes. Piedmont plains are formed along the Shivalik foothills by flooding hill torrents and nallahs (locally termed as 'Rao'). Alluvial plains are formed by unconsolidated to semi-consolidated deposits of sand, silt and clay. The study area is characterized as sub-tropical semi-arid climate. Soils are sandy loam to silt loam in texture and are excessive to well in drainage condition. Soils in hills contain large amount of coarse fragments and are characterized by skeletal soils belonging to Entisols. Soils in piedmont and alluvial plains are Entisols and Inceptisols soil orders, respectively. The average annual rainfall is about $1044 \mathrm{~mm}$, of which more than $80 \%$ occurs in the monsoon season (June-September).

\section{Materials and methods}

\subsection{Materials}

IKONOS $1 \mathrm{~m}$ resolution digital satellite data of November 2004 and Resourcesat-1 LISS-IV $5.8 \mathrm{~m}$ resolution data of 17 June, 2005 was used to generate thematic maps. Survey of India (SOI) topomaps on 1:25,000 scale were used for georeferencing of satellite data. Integrated Land and Water Information System (ILWIS) image processing and GIS software version 3.3 was used to generate the digital coverage of input parameters of the erosion model.

\subsection{Methods}

High resolution Resourcesat-1 and IKONOS satellite data were geo-referenced using WGS 84 Zone $44 \mathrm{~N}$ datum and Universal Transverse Mercator (UTM) projection. False Colour Composite (FCC) of IKONOS satellite data (November 2004) was 


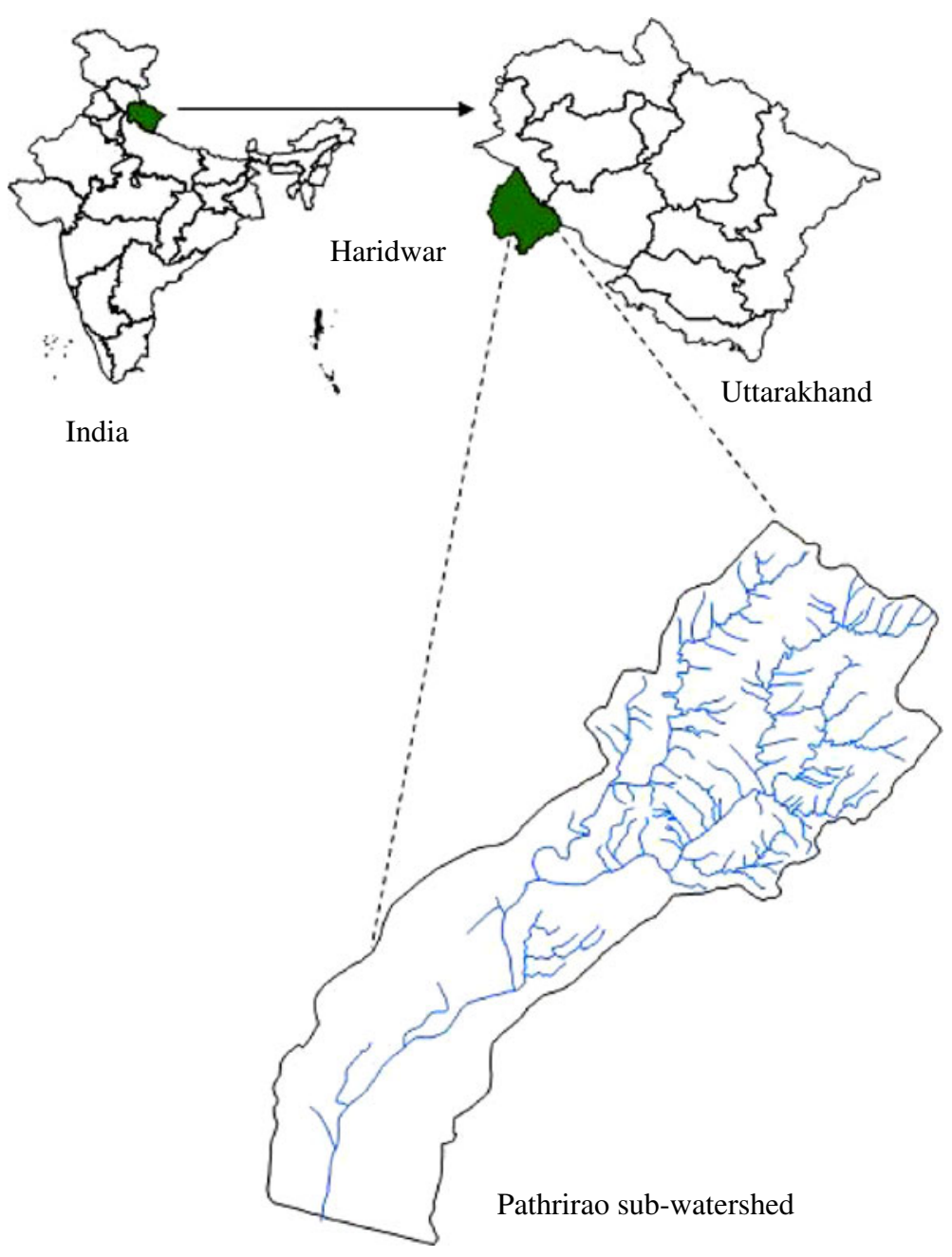

Figure 1. Location of the study area.

visually interpreted to map various land use/land cover types through on-screen digitization. Extensive ground survey was carried out in FebruaryMarch and October-November to collect information on various land use/land cover types in the area. Image characteristics such as tone, texture, pattern, shape and associations of various land use/land cover types on the FCC were established through field survey. Forest cover density was mapped into very dense $(>70 \%)$, dense (40-70\%), moderately dense (10-40\%) and open $(<10 \%)$ classes as per FSI (2009) by establishing image characteristics and field data of vegetation cover as well as information on terrain types and geomorphology of the area. A hand held Garmin Global Positioning System (GPS) receiver was used to obtain geo-coordinates of ground truth sites to ascertain their location on imagery. The interpreted map was field-verified to ascertain the classification accuracy (Kushwaha et al. 2010).

The information on management practices such as field size, shape, size of bunds and plantations along field boundaries followed by the farmers in agricultural and orchard land uses were collected during field survey. Agricultural fields in piedmont plains and near to streams/rivers had broken field bunds but raised and grassed field bunds in lower reaches of watershed in the alluvial plains. Forest area falling in Rajaji National Park had negligible human interference and no conservation measures were observed over there. This information helped to decide the management practice factor of various land use/land cover types.

Resourcesat-1 satellite imagery (standard FCC) of June 2005 was on-screen visually interpreted in conjunction with SOI topographical map (Sehgal et al. 1987) to delineate physiographic units for preparing the soil map on 1:25,000 scale. The study area was divided into Shivalik hills, piedmont plain, alluvial plain and flood plain landforms. Each landform was further sub-divided based on the slope and drainage density and land use/land cover, into 13 physiographic units having similar soil type. A detailed soil survey in a transect was undertaken to understand the landform, slope and land use/land cover and their relationship with soil. 
Field observations were also made for checking the physiographic boundaries. Representative soil profiles in each physiographic unit were exposed to study their morphological characteristics (Soil Survey Division Staff 2003). Soil permeability and soil structure were determined based on soil morphological characteristics. Horizon-wise soil samples were collected and analyzed for texture and organic carbon using standard analytical method (Jackson 1967).

\subsection{Model description}

The RUSLE-3D model calculates potential average soil loss $(A)$ as follows:

$$
A_{(r)}=R * K * L S_{(r)} * C * P
$$

where $A_{(r)}\left(\mathrm{t} \mathrm{ha}^{-1} \mathrm{y}^{-1}\right)$ is the average soil loss per year of a grid cell, i.e., at a point $r$ (geographic location of grid cell), $R$ (mt ha-cm ${ }^{-1}$ ) is the rainfall intensity factor, $K\left(\mathrm{t} \mathrm{ha}^{-1}\right.$ per unit $\left.R\right)$ is the soil erodibility factor, $L S_{(r)}$ (dimensionless) is the topographic (length-slope) factor at a grid cell $(r), C$ (dimensionless) is the land cover factor and $P$ (dimensionless) is the soil conservation or prevention practices factor.

\subsection{Generation of spatial data layers}

\subsubsection{Rainfall erosivity (R) factor}

The rainfall erosivity indicates the soil loss potential of a given storm event. The annual erosivity was estimated by summing rainfall erosivity of individual erosive storms of the year or season (Wischmeier and Smith 1978). It requires longterm data of rainfall amounts and intensities, which is not available for most of the area and hence, relationship between rainfall erosivity index and annual/seasonal rainfall was developed with the data available from various meteorological observatories in India (Singh et al. 1981). The linear annual and seasonal (June-September) relationship to erosion index was as follows:

$$
\begin{array}{ll}
Y=79+0.383 X & (r=0.83) \\
Y=50+0.389 X & (r=0.88)
\end{array}
$$

where $Y$ is the average annual erosion index $(\mathrm{mt}$ ha- $\mathrm{cm}^{-1}$ ) in equation (1) and average seasonal erosion index in equation (2), $X$ is the average annual rainfall $(\mathrm{mm})$ in equation $(1)$ and average seasonal rainfall $(\mathrm{mm})$ in equation $(2)$.

Nearest meteorological station for the subwatershed is located at National Institute of Hydrology, Roorkee, Uttarakhand, which received average seasonal rainfall of $856.5 \mathrm{~mm}$ per year
(June-September) for the period of 1995-2010. The rainfall erosivity index was estimated to be $383 \mathrm{mt}$ ha-cm ${ }^{-1}$ using equation (1). This value was used to predict average annual soil loss from the sub-watershed.

\subsubsection{Soil erodibility (K) factor}

Soil erodibility index $(K)$ of surface soils of each soil type, associated with the mapping units was computed using following equation:

$$
\begin{aligned}
K= & 2.8 * 10^{-7} \mathrm{M}^{1.14}(12-a) 4.3 * 10^{-3} \\
& \times(b-2) * 3.3 * 10^{-3}(c-3)
\end{aligned}
$$

where $K$ is the soil erodibility factor $\left(\mathrm{t} \mathrm{ha} \mathrm{h}^{-1}\right.$ per unit $R), M$ is particle size parameter (\% silt $+\%$ very fine sand $) *(100-\%$ clay $), a$ is the organic matter content (\%), $b$ is soil structure code and $c$ the soil permeability class. The soil map was reclassified based on $K$ value of each map unit to generate soil erodibilty map (figure 4a) using GIS.

\subsubsection{Spatial distributed slope length $(L)$ and steepness $(S)$ factors}

Contour lines of $20 \mathrm{~m}$ interval from SOI toposheets were digitized and interpolated to generate digital elevation model (DEM) with grid cell size of $20 \mathrm{~m}$ in GIS. DEM was processed to generate slope gradient and $L S$ factor maps. The average slope of each pixel (in percentage) was calculated from the greatest elevation difference between it and its eight neighbouring pixels. The slope was classified into eight steepness classes (Wischmeier and Smith 1978) of erosion hazards of nearly level (0-1\%), gently undulating (2-4\%), strongly undulating (4-6\%), gently rolling (6-10\%), strongly rolling (10-16\%), hilly (16-25\%), steep (25-40\%), very steep $(40-60 \%)$ and the extremely steep $(>60 \%)$ slope classes.

The $L S$ factor is the product of slope length and slope steepness factors (figure 4b). It was calculated for each grid cell. The slope length was replaced by the up-slope contributing area per unit width of cell spacing $A_{(r)}\left(\mathrm{m}^{2} \mathrm{~m}^{-1}\right)$ in RUSLE-3D (Mitasova et al. 1996). The modified $L S$ factor of a grid cell or at a point $\mathbf{r}=(x, y)$ is calculated as:

$$
L S_{(\mathbf{r})}=(m+1)\left[A_{(r)} / 22.13\right]^{m}\left[\sin \beta_{(r)} / 0.09\right]^{n}
$$

where $\beta_{(r)}$ is the land surface slope in degrees, $m$ and $n$ are constants equal to 0.6 and 1.3.

The DEM Hydro-Processing tool in ILWIS GIS software was used to calculate up-slope contributing area for each grid cell and equation (4) was implemented to estimate the $L S$ factor of each grid cell. 
Table 1. Land use/land cover, crop cover $(C)$ and conservation practice $(P)$ values.

\begin{tabular}{llccc}
\hline Sl. no. & \multicolumn{1}{c}{ Land use/land cover } & Area $(\%)$ & $C$ & $P$ \\
\hline 1 & Agriculture land-1 & 18.53 & 0.5 & 0.5 \\
2 & Agriculture land-2 & 7.08 & 0.3 & 0.4 \\
3 & Orchard & 2.05 & 0.1 & 0.5 \\
4 & Very dense forest & 6.88 & 0.004 & 1.0 \\
5 & Dense forest & 29.86 & 0.008 & 1.0 \\
6 & Moderately dense forest & 5.68 & 0.08 & 1.0 \\
7 & Open forest & 4.31 & 0.4 & 1.0 \\
8 & Dense scrub & 2.65 & 0.05 & 1.0 \\
9 & Forest blank & 0.28 & 0.8 & 1.0 \\
10 & Forest plantation & 5.42 & 0.02 & 0.8 \\
11 & Wasteland with scrub & 2.36 & 0.6 & 1.0 \\
12 & Wasteland without scrub & 5.92 & 1.0 & 1.0 \\
13 & Built-up (settlement) & 1.72 & - & - \\
14 & Mixed built-up land & 0.89 & 0.5 & 0.3 \\
15 & Water bodies (river/ponds) & 6.37 & - & - \\
& Total & 100.00 & - & - \\
\hline
\end{tabular}

\subsubsection{Crop cover $(C)$ and conservation practice $(P)$ factors}

In RUSLE model, estimation of $C$ factor takes into account a series of sub-factors that include prior land use, canopy cover, surface cover and surface roughness (Renard et al. 1991). Information on conservation practices $(P)$ followed in various land use/land cover classes were collected through field survey. Based on this information, $C$ and $P$ values for each land use/cover class (table 1) was assigned based on the literature (Roose 1977; Singh et al. 1981; Narain et al. 1994). Thereafter, CP factor map (figure 4c) was generated as an attribute map from the land use/land cover map using GIS.

\subsection{Predicting soil loss and erosion risk assessment}

The spatial data layers were input to RUSLE-3D model in GIS to predict the annual pixel level soil loss. Predicted soil erosion rate was classified into soil erosion risk classes (Singh et al. 1992): very low $\left(0-5 \mathrm{t} \mathrm{ha}^{-1} \mathrm{yr}^{-1}\right)$, low $\left(5-10 \mathrm{t} \mathrm{ha}^{-1} \mathrm{yr}^{-1}\right)$, moderate (10-15 t ha-1 $\left.\mathrm{yr}^{-1}\right)$, moderately high (15$\left.20 \mathrm{t} \mathrm{ha}^{-1} \mathrm{yr}^{-1}\right)$, high $\left(20-40 \mathrm{t} \mathrm{ha}^{-1} \mathrm{yr}^{-1}\right)$ and very high $\left(>40 \mathrm{t} \mathrm{ha} \mathrm{yr}^{-1}\right)$. Average annual soil loss of various land use/land cover types was estimated and analyzed to understand causes of erosion in the watershed in context to spatial distribution of erosion factors.

\section{Results and discussion}

Model input parameters were derived using remote sensing data and field survey and integrated in GIS environment to compute average annual soil loss to assess soil erosion risk area in the sub-watershed. Spatial distribution of land use/land cover, soil types and terrain characteristics and their influence on soil erosion potential are discussed as follows:

\subsection{Land use/land cover (LULC)}

The LULC classes (figure 2) were regrouped for assigning $C$ and $P$ factor values. The area under very dense, dense, moderately dense and open forest categories was 46.73, 38.44, 5.69 and $4.63 \%$, respectively. An area of $1.66 \%$ was noticed to be under orchards and $6.05 \%$ under forest plantations. Agriculture land covered $25.61 \%$ area grouped as agriculture land-1 used for wheat, groundnut, maize and mustard and agriculture land-2 for sugarcane, fodder and vegetables. Vegetation cover $(C)$ value of various LULC varied from 0.004 to 1.0 (table 1, figure 4c). Highest $C$ value was assigned to wasteland without scrub whereas lowest $C$ value was assigned to very dense forest cover.

Based on the conservation practices followed in various land use/land cover types in the area, $P$ factor values were assigned. Forest cover in the watershed belongs to Rajaji National Park and falls under Reserved Forest category. As such no mechanical or biological measures are adopted in forest area but it enjoys the protection from human interference. Thus, a conservation practice factor value of 1.0 was assigned to forest land and lands with scrub/rock out. Based on field management practices such as field bunds, tree plantation along field boundary, $P$ factor values were assigned. 


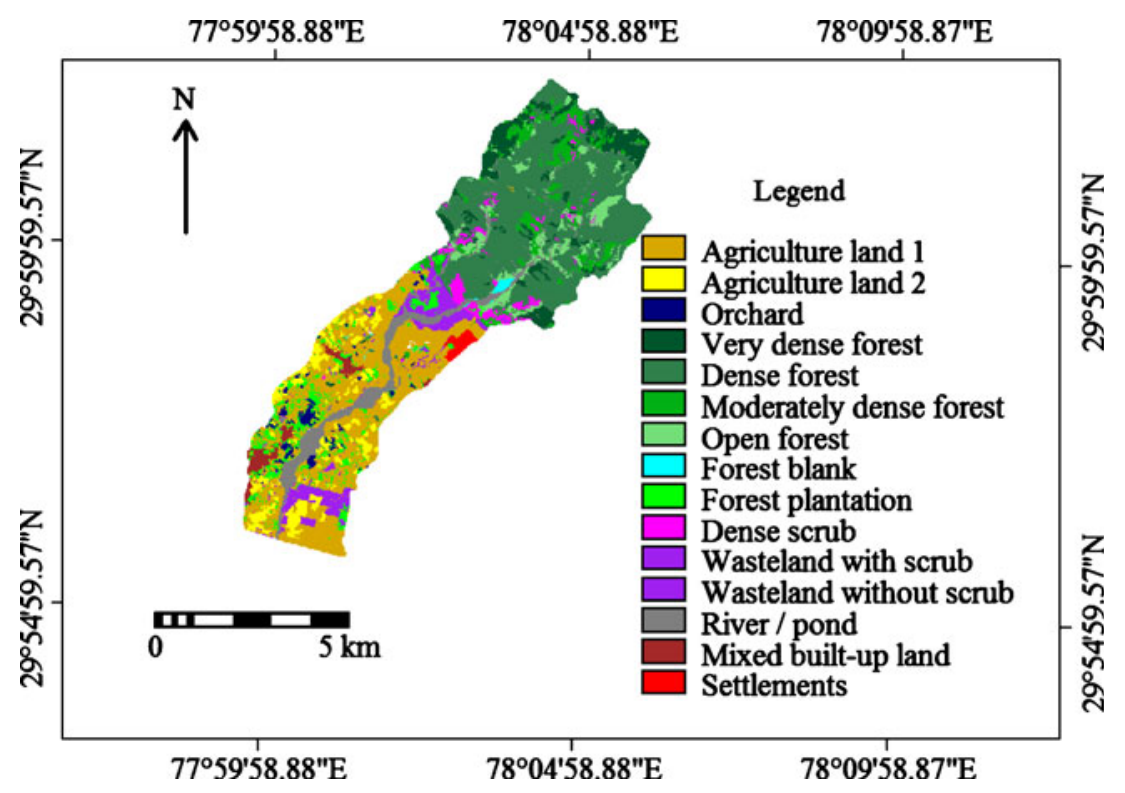

Figure 2. Land use/land cover.

Table 2. Soil erodibility factor $(K)$ values of soils in various physiographic-soil types.

\begin{tabular}{lcccc}
\hline Sl. no. & $\begin{array}{c}\text { Physiographic-soil } \\
\text { unit }\end{array}$ & $\begin{array}{c}\text { Texture } \\
\text { (surface })\end{array}$ & $\begin{array}{c}\text { O. C. } \\
(\%)\end{array}$ & $\begin{array}{c}\text { Soil erodibility } \\
\text { factor }(K)\end{array}$ \\
\hline 1 & $\begin{array}{c}\text { Steep to very steep } \\
\text { sloping Shivalik hills } \\
\text { Gentle to undulating } \\
\text { piedmont plain }\end{array}$ & sil/sl & $0.44-0.96$ & $0.30-0.38$ \\
3 & sl & $0.52-0.62$ & $0.32-0.35$ \\
Very gentle to nearly \\
$\begin{array}{l}\text { level alluvial plain } \\
\text { Nearly level } \\
\text { alluvial plain }\end{array}$
\end{tabular}

sl: sandy loam, sil: silty loam, ls: loamy sand.

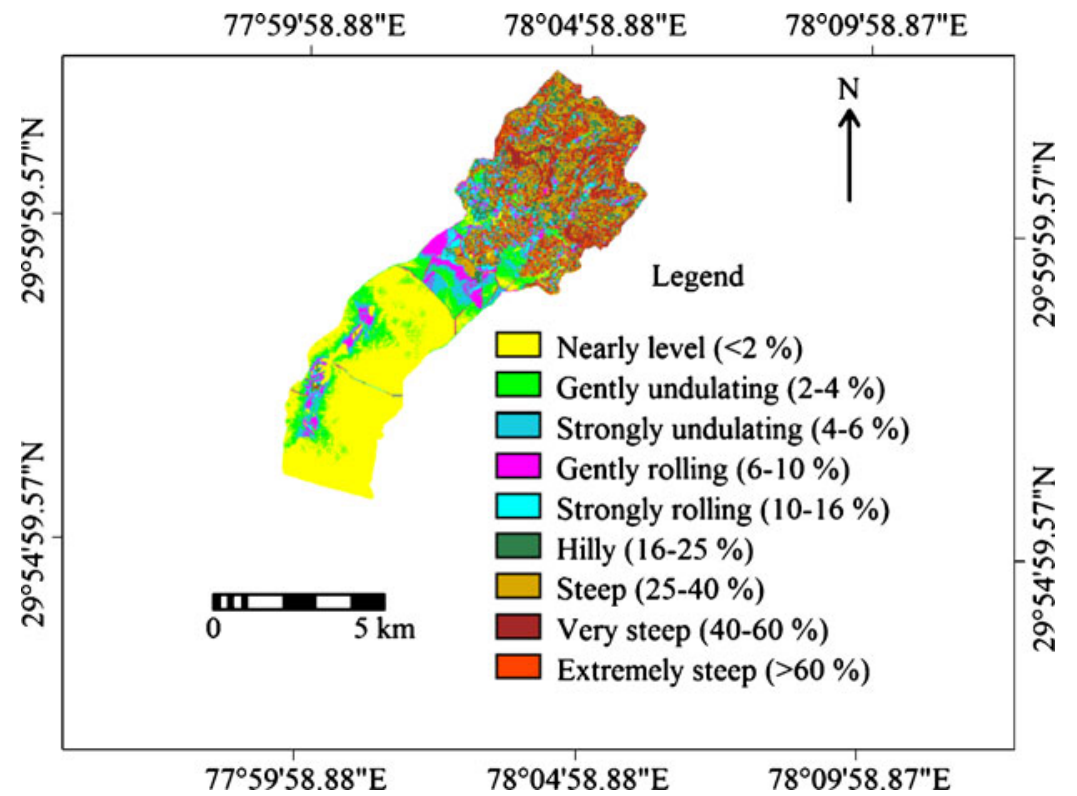

Figure 3. Slope (in percentage) classes. 


\subsection{Soil erodibility (K) factor}

Soil erodibility is an important index to evaluate the soil susceptibility to erosion. It reflects the combined effect of soil properties of texture, stability of structure, permeability and organic matter. Soil erodibilty increases as the soil texture becomes finer. Fine loamy soils (silt loam) have higher proportion of silt and very fine sand, making them more susceptible to erosion. Organic matter in the soil influences the aggregation of soil particles into stable soil structure. Soils with less than $3.5 \%$ organic matter are considered to be erodible (Evan 1980). Higher values of soil erodibility indicate its higher susceptibility to erosion. The soils in the watershed were characterized and soil erodibility of surface soils (figure 4a) were computed for each soil mapping units. Based on salient characteristics, soil map units were grouped into five major physiographic soil units (table 2). Soils in steep and very steep sloping Shivalik hills were characterized as excessively drained, shallow to moderately deep, silt loam to sandy loam texture and having $20-35 \%$ coarse fragments in the surface layer and their soil erodibility factor ranged from 0.30 to 0.38 . Piedmont plain soils were well drained, deep, sandy loam in texture and containing 15$20 \%$ coarse fragment in the surface layer and their soil erodibility factor ranged from 0.32 to 0.35 . Soils of alluvial plain lying below piedmont plains were characterized by silt loam to loam in texture in the surface layer. These soils were slightly more erodibile (0.38-0.44) compared to the soils of hills and piedmont plain. Soils of flood plains lying along river course were characterized as loamy sand to sandy loam texture and soil erodibility values ranged from 0.44 to 0.48 . Soils of flood plain had the highest soil erodibility due to low organic matter content. Soils of alluvial plains were more erodible than the soils of piedmont plain due to fine texture (silt loam) and low organic matter. Soils of the Shivalik hills were less erodible due to high organic matter content.

\subsection{Terrain slope and LS factor}

Spatial pattern of slope map (figure 3 ) revealed $43.78 \%$ area lies under nearly level to gently undulating and $31.85 \%$ area in steep to extremely steep slope classes, whereas $24.37 \%$ area belongs to strongly undulating to hilly slope classes. The $L S$ factor (figure $4 \mathrm{~b}$ ) accounts for the effect of slope length and gradient on soil erosion. Steep sloping area had higher steepness factor $(S)$ and lowest slope length $(L)$ factor. The highest slope length $(L)$ factor value was observed where overland flow tends to accumulate in the area of concave topography and the lowest in area of convex topography
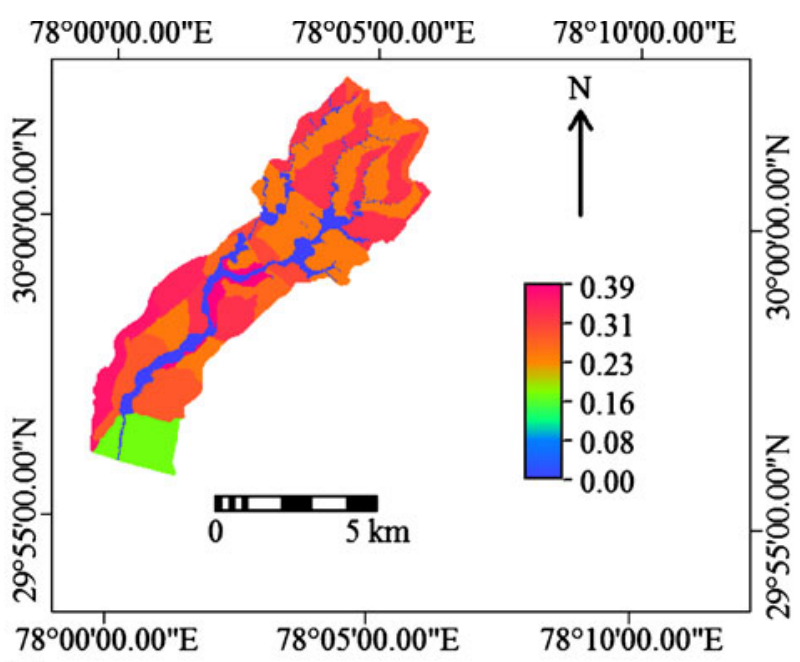

(a)

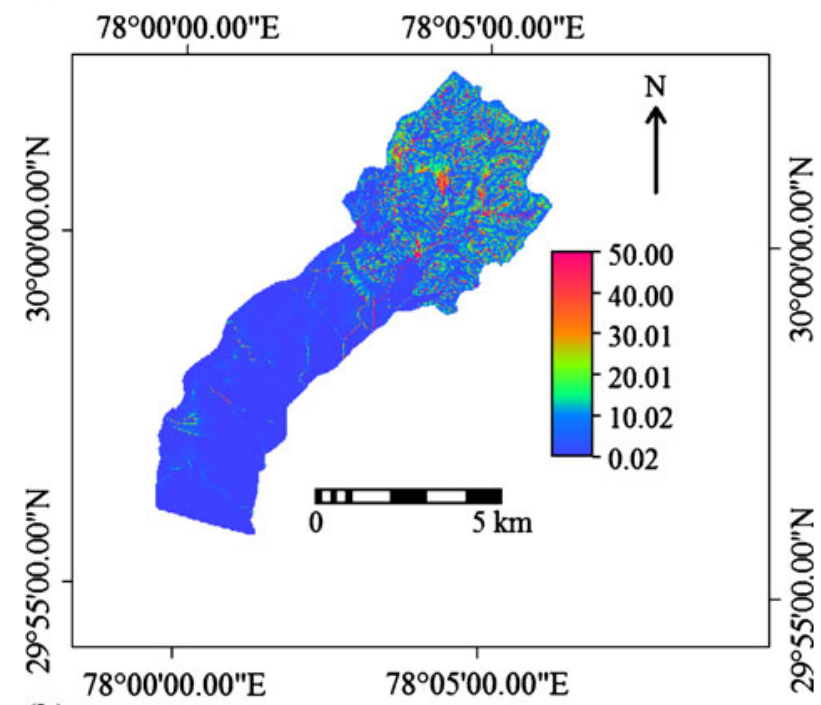

(b)

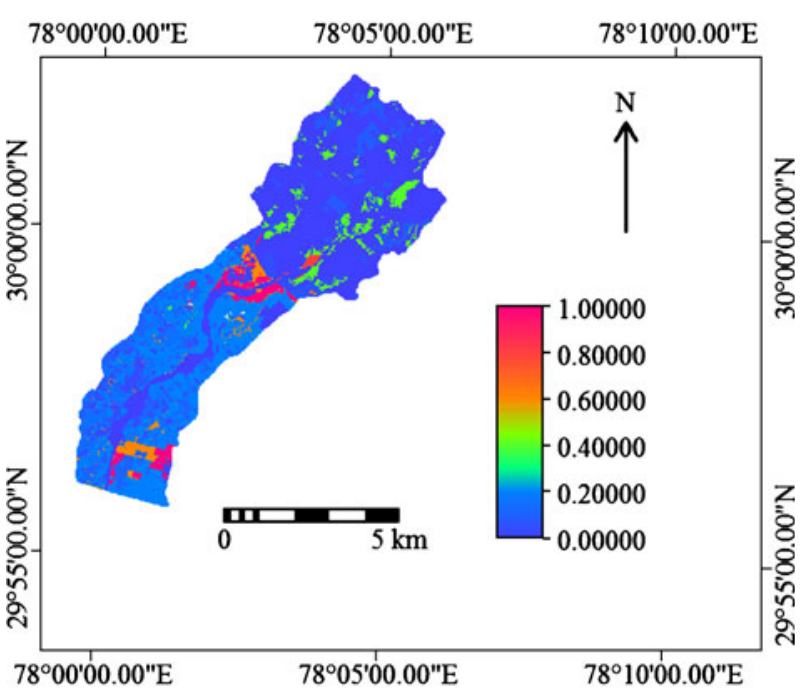

(c)

Figure 4. Soil erosion factors (a) soil erodibilty $(K)$, (b) topographic $(L S)$ and $(\mathbf{c})$ vegetation cover $(C P)$. 
such as ridge, where flow diverges (Hoyos 2005). However, area with higher slope had high $L S$ values. A comparison of $L S$ factor with slope gradient map revealed a distinct impact of steepness on $L S$ factor. Spatial analysis of $L S$ factor map of the watershed indicated that $49 \%$ area occurred mainly in piedmont plain with $<5 L S$ value. The average $L S$ factor value was estimated highest in hilly area (11.55) followed by piedmont plains (3.78), flood plain (1.34) and alluvial plains (0.94). It shows that the topographic $(L S)$ factor is largely controlling erosion processes in various landforms of the sub-watershed.

\section{Summary and conclusions}

Overland flow analysis showed that the overland flow from hills tends to concentrate in the piedmont plains; hence, slope length factor was computed higher in the piedmont plains. Accumulation of overland flow in the piedmont plains, mainly in upper part of it, has enhanced the soil erosion. The $L S$ factor was estimated to be the highest in hills followed by piedmont plains. Effect of higher $L S$ factor on soil erosion in Shivalik hills was counteracted by natural forest cover. Natural forest cover in the watershed increases the infiltration rate and thus reduces surface runoff and soil erosion (Woo and Luk 1990). Topographic and the vegetation cover factors are the most important factors affecting soil loss in mountainous watershed (King et al. 2005; Zhou et al. 2008). The average soil loss in Shivalik hills was predicted to be $35.47 \mathrm{t} \mathrm{ha}^{-1} \mathrm{yr}^{-1}$. Very dense forest cover has lowest soil erosion rate $\left(8.50 \mathrm{t} \mathrm{ha}^{-1} \mathrm{yr}^{-1}\right)$ whereas highest erosion rate (134.9 $\left.\mathrm{t} \mathrm{ha}^{-1} \mathrm{yr}^{-1}\right)$ is under open forest (figure 7 ) in the hilly landform. Open forest having very poor vegetation cover increases surface runoff and results higher soil erosion (Sidle et al. 2004). Moderately dense forest and open forest were predicted to have higher soil erosion rate than land with scrub or without scrub (fallow land). This could be attributed to the topographic factor. The forest cover in the hilly landform had high $L S$ factor than the land with or without scrub in the piedmont plains. The Shivalik hills experience high rate of soil erosion although being under forest cover as their soils are highly erodible of steep topography (Yadav et al. 2005). Topographic factor $(L S)$ appears to be most dominant in contribution of soil erosion in the Shivalik hills. Vegetation in these areas needs to be improved by adopting suitable conservation measures.

Average soil erosion rate was predicted moderately high (19.13 $\mathrm{t} \mathrm{ha}^{-1} \mathrm{yr}^{-1}$ ) for agriculture land-1, which needs appropriate soil conservation measures to reduce erosion. Agricultural land in piedmont plain was predicted to have an average soil loss of $35.92 \mathrm{t} \mathrm{ha}^{-1} \mathrm{yr}^{-1}$ and $14.67 \mathrm{t} \mathrm{ha}^{-1} \mathrm{yr}^{-1}$ in alluvial plain. Higher soil erosion rate in piedmont plain was attributed to higher topographic and soil erodibilty factors than in the alluvial plain. The flood plain along the river course was predicted to have higher soil erosion rate $\left(111.3 \mathrm{t} \mathrm{ha}^{-1} \mathrm{yr}^{-1}\right)$ as it was observed in the form of extension of river course in the sub-watershed.

Predicted average annual rate of soil loss was classified into five erosion risk classes (figures 5 and 6) to assess erosion potential severity. Nearly $59 \%$ area was classified as very low to low, $15 \%$ moderate to moderately high and $26 \%$ showed high to very high risk of soil erosion in the watershed. Nearly $16.88 \%$ area in Shivalik hills having forest cover and $11.98 \%$ area of piedmont and alluvial plains were predicted under moderate to very high risk of soil erosion in the watershed. Very high and high risk erosion areas in Shivalik hills were found to be associated with moderate steep to steep

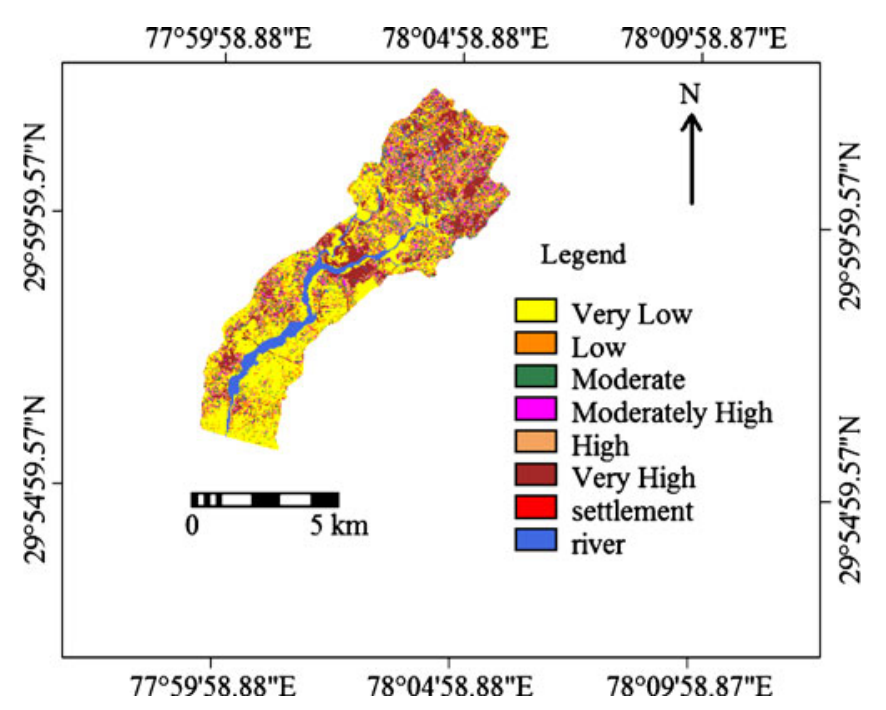

Figure 5. Soil erosion risk classes.

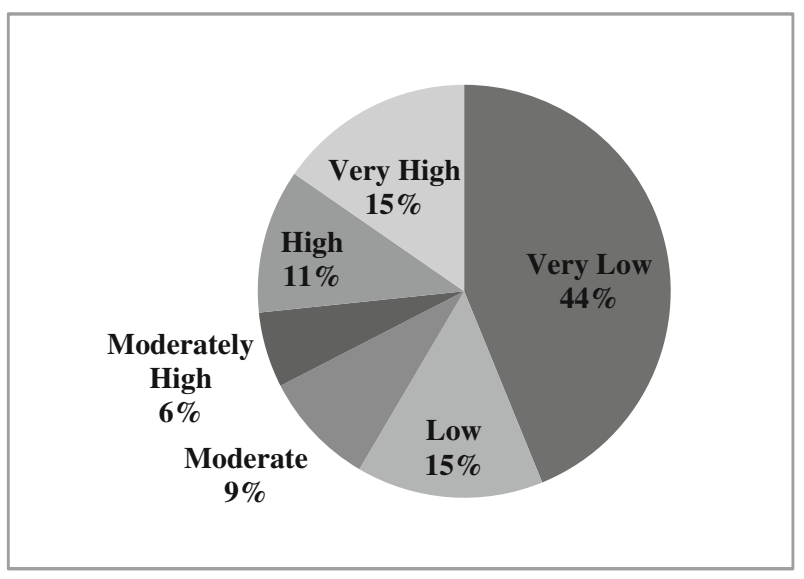

Figure 6. Percent areal extent under various soil erosion risk classes. 


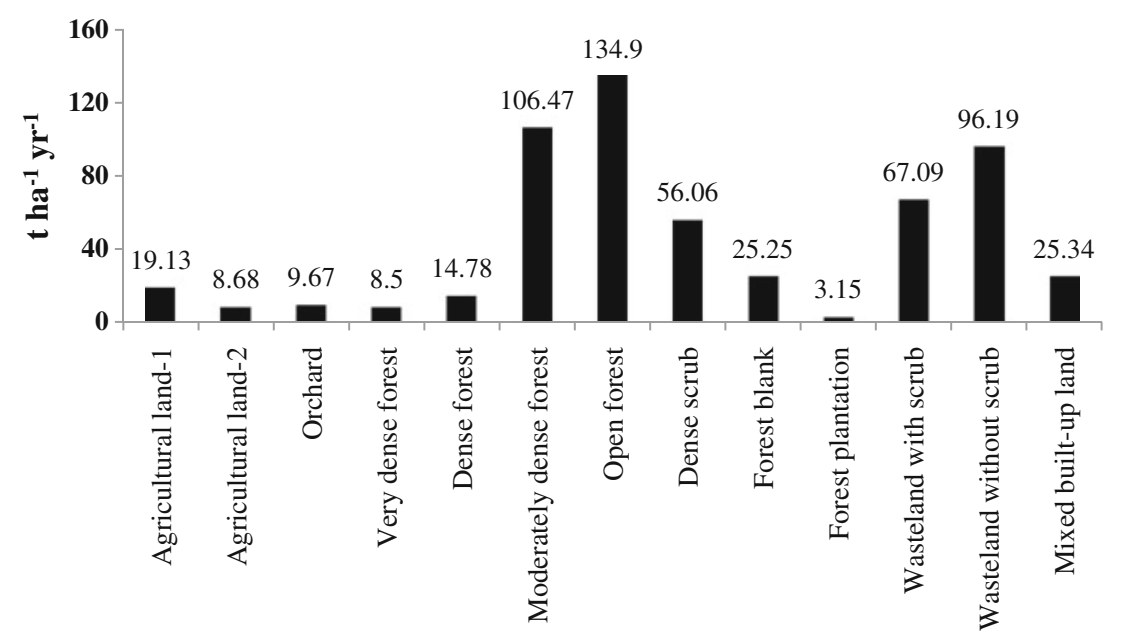

Figure 7. Average soil loss $\left(\mathrm{t} \mathrm{ha}^{-1} \mathrm{yr}^{-1}\right)$ in various land use/land cover types.

sloping area having scrub and open forest cover. Soil conservation measures such as bio-engineering measures need to be implemented in high to very high risk of soil erosion area to conserve surface runoff and thus reducing soil loss for enhancing vegetation cover and improving soil productivity in the watershed (Tiwari 2004) (figure 7).

The study illustrated use of GIS technology in quantitative spatial modelling of soil erosion to predict soil loss potential and to identify area of high erosion risk for soil conservation measures in the sub-watershed. Soil erosion factors were generated spatially and integrated in GIS to predict spatial pattern of soil erosion rate and were further classified into soil erosion risk map. High resolution remote sensing IRS Resourcesat-1 LISS-IV and IKONOS data helped to prepare detailed land use/land cover and soil maps and to derive vegetation cover, conservation practices and soil erodibility factor maps as input in the RUSLE-3D model. DEM was processed in spatial computation of slope length $(L)$ and steepness $(S)$ factors of the watershed. The average soil loss in flood plains and piedmont plains were predicted very high and high in Shivalik hills. Among various land cover classes, open forest on the hills was predicted to have the highest average soil loss followed by wasteland without scrub and moderately dense forest cover. Predicting spatial distribution of various erosion severities of these lands will help in adopting appropriate soil conservation measures to reduce soil erosion. Study demonstrated that RUSLE-3D model with GIS serves as robust and vital tool in identifying spatial distribution of soil erosion risk area in the watershed for soil conservation planning. Information on average soil erosion rate of various land use/land cover types helps to adopt suitable conservation measures for protecting soils from further erosion.

\section{Acknowledgements}

The authors wish to thank Director, Indian Institute of Remote Sensing for the encouragement and support during the course of the study. They also acknowledge the financial support from NRDMS, DST, Govt. of India, New Delhi for the project. Thanks are also due to the Chief Wildlife Warden, Uttarakhand for permitting them to work in subwatershed falling in the Rajaji National Park.

\section{References}

Arya S L and Samra J S 2001 Revisiting watershed management institutions in Haryana Shivaliks, India; Annual Report CSWCRTI, Research Centre, Chandigarh, pp. $104-105$.

CGWB 2009 Ground Water Brochure of Haridwar District; Central Ground Water Board (CGWB), Uttaranchal Region, Ministry of Water Resources, Government of India, Delhi.

Desmet P J J and Govers G 1996 A GIS procedure for automatically calculating the USLE $L S$ factor on topographically complex landscape units; J. Soil Water Conservat. $51427-433$.

Dhruva Narayana V V 1987 Downstream impacts of soil conservation in the Himalayan region; Mountain Res. Develop. 7(3) 287-298.

Efe R, Ekinci D and Curebel I 2008 Erosion analysis of Findikl creek catchment (NW of Turkey) using GIS based on RUSLE (3d) method; J. Appl. Sci. 8(1) 49-58.

Evan R 1980 Mechanics of water erosion and their spatial and temporal controls: An empirical viewpoint; In: Soil erosion (eds) Kirkby M J and Morgan R P C (Chichester: Wiley), pp. 109-128.

FSI 2009 State of Forest Report 2007, Forest Survey of India; Ministry of Environment and Forest, Dehradun.

Hoyos N 2005 Spatial modeling of soil erosion potential in a tropical watershed of the Colombian Andes; Catena 63 85-108.

IIRS 2007 Bio-geo database creation and sustainable development planning in Pathri Rao sub-watershed; Project 
Report submitted by Indian Institute of Remote Sensing (IIRS), NRDMS Division, Department of Science and Technology, Govt. of India, New Delhi.

Jackson M L 1967 Soil chemical analysis; Prentice Hall India Pvt. Ltd., New Delhi.

King C, Baghdadi N, Lecomte V and Cerdan 2005 The application of remote sensing data to monitoring and modeling of soil erosion; Catena 62 79-93.

Kushwaha S P S, Mukhopadhyay S, Hari Prasad V and Suresh Kumar 2010 Sustainable development planning in Pathri Rao sub-watershed using geospatial techniques; Curr. Sci. 98(1) 1479-1486.

Lal R 1998 Soil erosion impact on agronomic productivity and environment quality: Critical review; Plant Sci. $\mathbf{1 7}$ 319-464.

Lu D, Li G, Valladares G S and Batistella M 2004 Mapping soil erosion risk in Rondonia, Brazilian Amazonia: Using RUSLE, remote sensing and GIS; Land Degradation \&6 Develop. 15 499-512.

Millward A A and Mersey J E 1999 Adapting the RUSLE to model soil erosion potential in a mountainous tropical watershed; Catena 38(2) 109-229.

Mitasova H, Hofierka J, Zlocha M and Iverson L R 1996 Modelling topographic potential for erosion and deposition using GIS; Int. J. Geogr. Inform. Syst. 10 629-641.

Moore I D and Burch G J 1986 Physical basis of the lengthslope factor in the universal soil loss equation; Soil Sci. Soc. Am. J. 50(5) 1294-1298.

Moore D and Wilson J P 1992 Length-slope factors for the revised universal soil loss equation: Simplified method of estimation; J. Soil Water Conservat. 47 423-428.

Narain P, Khybri M L, Tomar H P S and Sindhwal N S 1994 Estimation of run-off, soil loss and USLE parameters for Doon valley; Indian J. Soil. Cons. 22(3) 129-132.

Park S, Oh C, Jeon S, Jung H and Choi C 2011 Soil erosion risk in Korean watersheds, assessed using the revised universal soil loss equation; J. Hydrol. 399(3-4) 263-273.

Popp J H, Hyatt D E and Hoag D 2000 Modeling environmental condition with indices: A case study of sustainability and soil resources; Ecol. Model. 130(1-3) 131-143.

Renard K G, Foster G R, Weesies G A, McCool D K and Yoder D C 1997 Predicting soil erosion by water: A guide to conservation planning with the revised universal soil loss equation (RUSLE); USDA Handbook, 703, U.S. Department of Agriculture, Washington, DC.

Renard K D, Foster G R, Weesies G A and Porter J P 1991 RUSLE Revised universal soil loss equation; J. Soil Water Conservat. 46(1) 30-33.

Risse L M, Nearing M A, Nicks A D and Laflen J M 1993 Error assessment in the universal soil loss equation; Soil Sci. Soc. Am. J. 57(3) 825-833.

Roose E J 1977 Application of the universal soil loss equation of Wischmeier and Smith in West Africa; In: Soil conservation and management in the humid tropics (eds) Greenland D J and Lal R London; Wiley, pp. 177-187.
Sehgal J L, Saxena R K and Vadivelu S 1987 Field Manual Soil Resource Mapping of different states in India; Tech. Bull. NBSS Publ. 13, NBSS\&LUP, Nagpur.

Sidhu G S, Walia C S, Sachdev C B, Rana K P C, Dhankar R P, Singh S P and Velayutham M 2000 Soil resource of NW Shivaliks for prospective land use planning; In: Fifty Years of Research on Sustainable Resource Management in Shivaliks (eds) Mittal S P, Aggrawal R K and Samara J S, Central Soil \& Water Conservation Research and Training Institute, Research Centre Chandigarh, India, pp. $3-34$.

Sidle R C, Taylor D, Lu X X, Adger W N, Lowe D J, deLange W P, Newnham R N and Dodson J R 2004 Interactions of natural hazards and society in Austral-Asia: Evidence in past and recent records; Quart. Int. 118/119 181-203.

Singh G, Ram Babu and Chandra S 1981 Soil loss prediction research in India; Tech. Bull. T-12/D-9, Central Soil and Water Conservation Research and Training Institute, Dehradun, India.

Singh G, Ram Babu, Narain P, Bhusan L S and Abrol I P 1992 Soil erosion rates in India; J. Soil Water Conservat. 47(1) 97-99.

Shi Z H, Cai C F, Ding S W, Wang T W and Chow T L 2004 Soil conservation planning at the small watershed level using RUSLE with GIS: A case study in the Three Gorge Area of China; Catena 55 33-48.

Soil Survey Division Staff 2003 Soil Survey Manual; Handbook 18, USDA, Washington DC.

Terranova O, Antronico L, Coscarelli $\mathrm{R}$ and Iaquinta $\mathrm{P}$ 2009 Soil erosion risk scenarios in the Mediterranean environment using RUSLE and GIS: An application model for Calabria (southern Italy); Geomorphology 11(3-4) 228-245.

Tiwari A K 2004 Effective bio-engineering measures for torrent and erosion control in Shivaliks; In: Compendium National Symposium on enhancing productivity and sustainability in hill and mountain agro-ecosystem (ed.) Sharda V N, CSWCRTI, Dehradun.

Valdiya K S and Bartarya S K 1989 Problem of mass movements in a part of Kumaun Himalaya; Curr. Sci. 58 486-491.

Wischmeier W H and Smith D D 1978 Predicting rainfall erosion losses: A guide to conservation planning; USDA Handbook, 537p.

Woo M and Luk S 1990 Vegetation effects on soil and water losses on weathered granitic hillslopes, south China; Phys. Geogr. 11 1-16.

Yadav R P, Aggarwal R K, Bhattacharyya P and Bansal R C 2005 Infiltration characteristics of different aspects and topographical locations of hilly watershed in Shivaliklower Himalayan region in India; Indian J. Soil Conservat. 33(1) 44-48.

Zhou P, Luukkanen O, Tokola T and Nieminen J 2008 Effect of vegetation cover on soil erosion in a mountainous watershed; Catena 75 319-325. 